
$\$$ Research Square
Preprints are preliminary reports that have not undergone peer review.
They should not be considered conclusive, used to inform clinical practice, or referenced by the media as validated information.

\title{
Job Satisfaction, Engagement and Associated Factors among Employees Working at Adama Hospital Medical College, Adama, Oromia Regional State, Ethiopia: Institution Based Cross Sectional Study
}

Ebrahim Mohammed ( $\nabla$ ebrahim.m805@gmail.com )

Addis Ababa University School of Medicine https://orcid.org/0000-0002-7416-8741

Haji Aman Daybaso

Jimma University College of Public Health and Medical Sciences

Ephrem Mannekulih Habtewold

Adama Hospital Medical College

Research

Keywords: Job, Job Satisfaction, job engagement, Employee, Adama Hospital Medical College

Posted Date: August 10th, 2020

DOl: https://doi.org/10.21203/rs.3.rs-54587/v1

License: (1) (i) This work is licensed under a Creative Commons Attribution 4.0 International License.

Read Full License 


\section{Abstract}

Introduction: High level of professional satisfaction among health workers earns high dividends such as higher worker force retention and patients satisfaction

Objective: To assess level of employeessatiaction and associatedfac $\rightarrow$ rsamongemployees working in Adama hospital medical college town from January to March 2019.

Methods: institution based cross-sectional study design was employed. About 389 employees were interviewed.Multi variable logistic regression analysis was used to identify the relationship among predictors and outcome variable. P-value $<0.25$ will be used as cutoff point for variable to be candidate for multi variable logistic regression. P-value $<0.05$ and Adjusted odds ratio at $95 \%$ level of significance will be used to declare predictors of employees satisfaction.

Results: A total of 389 study participant responded to the questionnaires with response rate of $92.20 \%$. More than half $212(54.5 \%)$ were male and the mean age of study participants were 32.24 years (SD \pm 7.87). The overall level of job satisfaction was $185(47.6 \%)(95 \% \mathrm{Cl}: 1.43,1.53)$. Factors like shisha smoking (AOR, 0.4; 95\% Cl: 0.01, 0.44), Co-workers relationship (AOR, 2.85; 95\% Cl: 1.21, 6.72), working environment (AOR, 4.08; 95\% Cl: 1.98, 8.41), autonomy at their working (AOR, 4.40; 95\% Cl: 1.89, 11.19), commitment for their organization (AOR, 2.48; $95 \% \mathrm{Cl}$ : 1.20, 5.10), performance evaluation (AOR, 5.69; $95 \% \mathrm{Cl}: 2.53,12.80)$, promotion or growth opportunity (AOR, 9.58; $95 \% \mathrm{Cl}: 4.11,22.32$ ) and relationship with immediate supervisor (AOR,4.59; $95 \% \mathrm{Cl}$ : 1.89, 11.19) shows significant association with employees job satisfaction.

Conclusion and recommendation: The overall level of employees satiactionislow. The or ganizationshodw or konfac $\rightarrow$ rsassociatedwithemployees job satisfaction in order to increase satisfaction levels of employees.

\section{Introduction}

An organization should recognize the benefits of human resource it controls. By benefits means resources that could be utilized to generate profits for the organization. Resources are things that contribute to the strength or weakness of an organization(1). Satisfaction is one of the competitive advantages which help organization to grow internally and externally in working environment. Satisfaction is the act of fulfilling a need, desire, appetite or the feeling gained from such fulfilment. Satisfaction means you have had enough fulfilment of your desire, need and feeling(2). The construct of employee satisfaction is important as satisfied employees can do more for organization in shape of better performance and productivity(3).

Employees' satisfaction is the individual employee general attitude towards the job. It is also an employee cognitive and affective evaluation of his or her job. According to New Cranny, Smith and Stone 
(1992), Employee satisfaction is defined as the combination of affective reactions to the differential perceptions of what he/she wants to receive compared with what he/she actually receives(4). Spector (1997), defined employee satisfaction, as all the feelings that a given individual has about his/her job and its various aspects(5).

Employee Satisfaction has significant impact on job performance and has benefits; Increase Employees Performance, creates strong organizational commitment, increase Employees Morale, decrease Absenteeism, Low Turnover, and creates Positive Mental Attitude, Increase Customer Satisfaction, Organization Success and Reduce Union Activities(6).

A person with high level of job satisfaction holds positive attitude towards the job

while a person who is dissatisfied with his or her job holds negative attitude about the job (7). Employee satisfaction and Job satisfaction is used interchangeably(8). Employee satisfaction is connected to usage of human resources and influences the quality and amount of work done describes the impact of employee satisfaction on customer satisfaction. According to New Cranny, Smith and Stone (1992), Employee satisfaction is defined as the combination of affective reactions to the differential perceptions of what the employees' wants to receive compared with what he/she actually receives (4)

Job satisfaction reflects the extent to which individuals find fulfilment in their work. Job satisfaction is an affective or emotional response towards various facets of one's job. In other words, job satisfaction involves a person's positive or negative feelings about his or her job(9).Job satisfaction refers to a collection of opinions that an individual holds towards his or her job. A person with a high level of job satisfaction holds a positive feeling about the job, while a person who is dissatisfied with his/her job holds a negative feeling about the job(10).

In America, $38 \%$ of employee were very satisfied with their current job(11). In study conducted in higher education in Ethiopia, most of employee was moderately satisfied with their job but with specific job dimension, the highest dissatisfaction level was occurred in the area of salary and fringe benefits(12). Many studies have been conducted in different parts of Ethiopia to assess Employees satisfaction. In study conducted in western parts of Ethiopia, the overall level of job satisfaction among employees was $41.46 \%(13)$. In another study conducted in Ethiopia at western Amhara region the overall job satisfaction of health professional working at Western Amhara region was $31.7 \%(14)$. In study conducted in Mekelle University among academic staff, about $50.4 \%$ of employees satisfied(15). In study conducted in West Gojam among nurses professionals and health care workers in Jima University the level of job satisfaction were $54.2 \%$ and $46.2 \%$ respectively $(16,17)$. In another study conducted in south west region of Ethiopia among nurses working in public hospitals, the overall satisfaction level was high(67.43\%) compared to different types of studies conducted in different parts of Ethiopia(18). In studies conducted another part among Anesthesia professionals and Midwives the overall level of employees satisfaction was $42.5 \%$ and $52.9 \%$ respectively $(19,20)$. Employees 'satisfaction can be influenced by the factors like salary, working environment, autonomy, communication, and organizational commitment $(21,22)$. But in study conducted in Bangiladish pharmaceutical company, it shows that factors like working conditions, 
pay and promotion, job security and relationship with co-workers the study found that there is effect on level of employee job satisfaction but the relationship with immediate supervisor shows negative effect on employee satisfaction(23).

Study conducted in Sidama zone, Ethiopia, on factor influencing Nurses job satisfaction, shows that factors like working experience of staffs, age, institutions, sex, and working unit of nurses shows significant association to overall satisfaction of workers(24). In another study conducted in Pakistan, factors like Participation in decision making, empowerment, reward and recognition, work place environment are the four major factors that affect the employee job satisfaction(25). In study conducted by Sharma and Khanna in 2014 on bank workers, factors like Salary of employees, performance appraisal system, promotional strategies, employee's relationship with management and other coemployees, training and development program, work burden and working hours are found important for improving job satisfaction of bank employees in banks(26).

A study conducted in Solevenian hospital by Lorber and Savic in 2012, suggested that "Job satisfaction is positively correlated with leadership style, managerial competencies and personal characteristics of leaders"(27). Kadarisman in 2012 concluded that "salary, benefits and facilities, the relationship between superiors and subordinates, the relationship among co-workers, development opportunity, safety at work, education, Policies within the organization, conflict resolution and career achievements are the dominant factor that affects the job satisfaction in government organization"(28).

According to the conclusion made by the study conducted in Delhi, India, made on the government employees' satisfaction level, factors like Job security and Supervisory support, Appreciation and Salary, Job Engagement and Autonomy, Job Advancement, Empowerment and Job Enrichment are the factors that enhance the job satisfaction of employees(29). In another study conducted in Bangladesh pharmaceutical company, Employees" are satisfied with the recruitment and selection, and training and development policy and practices of pharmaceutical companies. On the other hand, employees are dissatisfied with the human resource planning, working environment, compensation policy, performance appraisal, and industrial relations(23).

Study conducted in western part of Ethiopia among health professional working in public health center, factors like Compensation (benefits), recognition by management, and opportunity for development were associated with job satisfaction. A unit increase in salary and incentives and recognition by management scores resulted in 0.459 and 0.156 unit increases in job satisfaction scores, respectively(13). In another study conducted in Western Amhara region, Ethiopia, factors like presence of health professionals' reference manual/ guide, alcohol drinking, workload, experience, educational status and profession types were found to be significant factors associated with health care professionals' job satisfaction level. Professional being laboratory technicians, pharmacists and Environmental health workers were 4.86 times more likely to be satisfied than nurses, midwives and Public health officers. Similarly, Educational status, degree and above holders were 5.64 times more likely to be satisfied than below degree holders. Work experience of Health professionals with $>3$ years shows significant association, which were 2.83 
times more likely to be satisfied than counterpart. Health professionals who had high workloads were 3.99 times more likely to be satisfied than those professionals whose workload was low. Professionals who did not drink alcohol were 3.55 times more likely to be satisfied than professionals who drank. Professionals who consult health reference manual/guide were 15.96 more likely to satisfy themselves than those professional who did not(14). Nature of work made satisfies and promotion made dissatisfied employees` among Nurses working in East Gojjam Zone Public Hospitals Northwest Ethiopia(16). In study conducted among Anesthesia professionals, Work environment (1.87), and more than 10 years of experience working in the public health system (4.96) were found to be predictors of job satisfaction(19).

In one the study conducted in Addis Ababa, Ethiopia, Independent factors like Sex, working unit, Educational status, Marital status, supervision, standard of care and work load were found to be predictors of job satisfaction. Midwives were least satisfied from salary, extrinsic reward and professional opportunity subscales but were satisfied by co-worker relation and the standard of care they provided to clients(20). This study will help managers so that they have better understanding about the factors affecting the job satisfaction of employees and shows what they should do to alleviate the factors affecting employee's job satisfaction and help them to improve their customers dissatisfaction.

\section{Conceptual Framework}

Conceptual framework for this study organized in the following manner and developed from the literature reviewed above.

(Fig. 1; conceptual framework here)

\section{Objectives}

\subsection{General Objective}

To assess level of employeessatiaction and associatedfac $\rightarrow$ rsamongemployees working in Adama Hospital Medical College from January to March 2019

\subsection{Specific objectives}

- To assess level of employeessatiactionamongemployees working in Adama Hospital Medical College from January to March 2019.

- To identify factors associated with level of employeessatiactionamongemployees working in Adama Hospital Medical College from January to March 2019.

\section{Methods And Materials}

\subsection{Study area and Period}


The study was conducted in Adama Hospital Medical College, in Adama town, Oromia Regional State, Ethiopia. Adama town is located at about $100 \mathrm{Km}$ South-East of Addis Ababa in the great rift valley of east Africa. Adama Town is one of the big cities of Ethiopia with an area of 13000 square $\mathrm{m}^{2}$ and has a total population of 337,556. In Adama Hospital Medical College, there are more than 599 workers including both health care professional and administrative staffs.

\subsection{Study Design}

Health Facilities based cross sectional study design was employed among workers working in the hospitals found in Adama town from January to March 2019.

\subsection{Source population}

All employees working in Adama Hospital Medical College.

\subsection{Study Population}

The study populations included all workers working in Adama Hospital Medical College.

\section{4.1 Inclusion criteria}

All workers working in AHMC at the time of study period will be included in this study.

\subsubsection{Exclusion criteria}

Workers who are on annual leave, who newly joined the AHMC in the last six months, Workers who are on education and who are not volunteer was excluded.

\subsection{Sample Size Determination}

The sample size was determined by using a formula for estimation of a single population proportion. The population proportion $(50.4 \%$ ) for sample size calculation taken from the study result conducted at Mekelle university academic employees'(15). $5 \%$ precision and $10 \%$ of the sample size was added to compensate for non-response. Therefore, the sample size was 


$$
\mathrm{n}=\underline{\mathrm{z}}_{\underline{\alpha} 2^{2}} \underline{\mathrm{p}}(1-\underline{\mathrm{p}})
$$

$d^{2}$

\section{Where:}

$$
\begin{aligned}
& \checkmark n=\text { number of employee }, \\
& \checkmark \quad p=\text { proportion of employee satisfaction among academic staffs in Mekelle university } 50.4 \%, \\
& \checkmark \quad D=\text { estimated margin of error for the study, } 5 \% \text { and } \\
& \checkmark \quad z_{\alpha / 2}=\text { the standard normal distribution } z \text { value of } 1.96 \text { (at } 95 \% \text { level of confidence). } \\
& n=\underline{(1.96)^{2} \times(0.0504)(0.496)}=384
\end{aligned}
$$

About 10\% (38) non response rate was added to calculate sample and the final sample size become 422.

\subsection{Sampling procedure}

Stratified sampling method was used. Employees` working in the AHMC was stratified based on their profession, like General Practitioners', Nurses, Midwives, Pharmacy Professionals, Radiography Professionals, Laboratory Professionals, Anesthesia Professionals, Academic Staffs and Administrative staffs. Sample size was allocated proportionally among each stratum. Finally simple random sampling is used to select the study sample from each stratum. Sample size was allocated based the following formula;

$$
\begin{aligned}
& \mathrm{N}=\text { total sample size required(n) X Number of employees in each hospital }(\mathrm{Z})=\underline{\mathrm{nXZ}} \\
& \text { Total number of employees' in the hospitals (w) } \\
& \text { W }
\end{aligned}
$$

(figure 2 sampling procedure here)

\subsection{Variables}

\subsubsection{Dependent variable}




\subsubsection{Independent variables}

Age, Ethnicity, Religion, Educational status, Marital Status, Freedom or autonomy, Job security, Relationship with co-workers, Relationship with superior, Salary, Benefit and compensation, growth and Career advancement, communication, and organizational commitment, decision making, empowerment, reward and recognition, performance appraisal system, promotional strategies, leadership style, managerial competencies and personal characteristics of leaders.

\subsection{Data collection procedures}

Self-administered questionnaires were used to collect data from employee. Questionnaires were distributed to randomly selected samples from each stratum. The questionnaires was be adopted from similar studies conducted in Ethiopia and modified based on the objectives of the study $(15,16,20)$. Mixed type of questions (structured and semi-structured) and likert scale type questionnaires were used to collect the data. The questionnaires was prepared in English and translated into two commonly locally spoken languages, Afan Oromo and Amharic in the study area by Bsc holder of language for administrative staffs. The translated questionnaire was re-translated back to English by Language teachers in another preparatory school in Adama to check its consistency.

\subsection{Data Quality assurance}

Data was collected by trained data collectors. Data collection training was given for both data collectors and supervisors for 2 days including pre-test finding discussion and correction of data collection tools. Pre-test of data collection was done in the Olenchiti hospital 1 week before data collection date. About 42 (5\%) of the sample size was used for pre-test. Then the data from pre-test was analysed and questionnaires were re-adjusted based on the response from the pre-test. The data collection was started after one week of pre-test data collection. The data were checked for completeness and accuracy and corrected on the spot by supervisors. The investigators and supervisors were meeting and discussed daily at the end of working hours of the data collection. Those data found missing in addressing important variables like the outcome and other important variables was discarded and no longer was used as a predictor variable. The data were stored in a secured place for confidentiality and in time of need for a backup of the data.

\subsection{Data Processing and Analysis}

Before the start of analysis, data was coded and entered into computer using SPSS version 21 statistical software. Univariate and multivariate logistic regression was done. Univariate logistic regression analysis was done to determine the preliminary relationship between the independent and dependent variables. 
Collinarity and assumption of goodness of fit was checked using Hoshmer and Lemshow test and assumption of goodness of fit respectively. Finally, a variable which was found significant at $P<0.25$ on Bivariate analyses was taken to multivariable logistic regression to identify the independent predictors of employees satisfaction among AHMC workers. Backward logistic regression method will be used. Results from the multivariable logistic regression were reported in the form of adjusted odds ratios (AORs), with a $95 \%$ confidence interval $(\mathrm{Cl})$ at the level of significance of 0.05 .

\subsection{Ethical Considerations}

The ethical approval and clearance was obtained from AHMC IRB (Ethics Review Committee). All hospitals and respective officials in Adama hospital medical college were communicated before the start of the study. All the study participants were informed about the purpose of the study and verbal consent of all study subjects were obtained before data collection. Participants were informed that they have full right to discontinue or refuse to participate in the study or to be interviewed. Confidentiality was ensured, the name of the interviewee was not written on the questionnaire. Each respondent was assured that the information they provide will be kept confidential and used only for the purpose of research. Moreover, the study participants were informed there is no risk or harm that was anticipated from participation in the study.

\section{Result}

\subsection{Socio-demographic characteristics}

A total of 389 workers were participated in the study accounting $92.2 \%$ of response rate. Out of the total study participants $212(54.5 \%)$ were male. The mean age of study participants were 32.24 years (SD \pm 7.87). Concerning the religion of study participants, the majority $149(38.3 \%)$ was orthodox and followed by $94(24.2 \%)$ Muslim. The majority of the study participants $298(76.6 \%)$ were Oromo and $257(66.1 \%)$ were married. Regarding their educational status, the majority $262(67.4 \%)$ of them holds first degree and $108(42.0 \%)$ of partners of study participants finish their first degree level education. Concerning the profession of the study participants, the majority 141 (36.2\%) were nurses followed by $109(28.0 \%)$ administrative staffs. The majority $158(61.5 \%)$ of study partners were government employee. Less than half $185(47.6 \%)$ of the study participants earns less than 5000 Eth. birr per month. More than two third $311(79.9 \%)$ of study participants said that they do not get any payment other than salary and duty hour payment from AHMC and 329(84.6\%) do not have another source of income than their salary and duty hour payment.

(Table 1; Socio-demographic characteristics of AHMC workers, here ) 
Table 1

Socio-demographic characteristics of AHMC workers, 2019

\begin{tabular}{|c|c|c|}
\hline Variables & Frequency & Valid Percent \\
\hline \multicolumn{3}{|l|}{ Sex } \\
\hline Male & 212 & 54.5 \\
\hline Female & 177 & 45.5 \\
\hline \multicolumn{3}{|l|}{ Age } \\
\hline $20-30$ yrs. & 212 & 54.5 \\
\hline $31-40$ yrs. & 126 & 32.4 \\
\hline $41-50$ yrs. & 37 & 9.5 \\
\hline$>50$ yrs. & 14 & 3.6 \\
\hline \multicolumn{3}{|l|}{ Religion } \\
\hline Orthodox & 149 & 38.3 \\
\hline Muslim & 94 & 24.2 \\
\hline Protestant & 124 & 31.9 \\
\hline Others & 22 & 5.7 \\
\hline \multicolumn{3}{|l|}{ Ethnicity } \\
\hline Oromo & 298 & 76.6 \\
\hline Amhara & 68 & 17.5 \\
\hline Others & 23 & 5.9 \\
\hline \multicolumn{3}{|l|}{ Marital Status } \\
\hline Married & 257 & 66.1 \\
\hline Not Married & 102 & 26.2 \\
\hline Divorced/Widowed & 30 & 7.7 \\
\hline \multicolumn{3}{|l|}{ educational Status } \\
\hline Below level IV/Diploma & 31 & 8.0 \\
\hline Level IV/Diploma & 66 & 17.0 \\
\hline 1st degree & 262 & 67.4 \\
\hline 2nd degree & 30 & 7.7 \\
\hline Partners educational Sta & & \\
\hline
\end{tabular}




\begin{tabular}{|c|c|c|}
\hline Variables & Frequency & Valid Percent \\
\hline Primary & 21 & 8.2 \\
\hline Secondary & 32 & 12.5 \\
\hline Level IV/Diploma & 77 & 30.0 \\
\hline 1st degree & 108 & 42.0 \\
\hline 2nd degree & 19 & 7.4 \\
\hline \multicolumn{3}{|l|}{ Partners Occupation } \\
\hline House Wife & 58 & 22.6 \\
\hline Gov. Employee & 158 & 61.5 \\
\hline Private Company Employee & 26 & 10.1 \\
\hline Others & 15 & 5.8 \\
\hline \multicolumn{3}{|l|}{ Professional Status } \\
\hline Nurse & 141 & 36.2 \\
\hline Midwife & 31 & 8.0 \\
\hline G/Practitioner/MD & 8 & 2.1 \\
\hline Pharmacy Professional & 17 & 4.4 \\
\hline Laboratory Professional & 21 & 5.4 \\
\hline Radiology Professional & 20 & 5.1 \\
\hline Specialist & 26 & 6.7 \\
\hline Administrative staffs & 109 & 28.0 \\
\hline Others & 16 & 4.1 \\
\hline \multicolumn{3}{|l|}{ Salary } \\
\hline$<5,001$ Eth. birr & 185 & 47.6 \\
\hline $5,001-10,000$ Eth. birr & 155 & 39.8 \\
\hline$>10,000$ Eth. birr & 49 & 12.6 \\
\hline \multicolumn{3}{|c|}{ Payment other than Salary and Duty from AHMC } \\
\hline No & 311 & 79.9 \\
\hline Yes & 78 & 20.1 \\
\hline
\end{tabular}




\begin{tabular}{|l|ll|}
\hline Variables & Frequency & Valid Percent \\
\hline No & 329 & 84.6 \\
\hline Yes & 60 & 15.4 \\
\hline Years of experience & & \\
\hline$<5$ years & 141 & 36.2 \\
\hline $5-10$ years & 169 & 43.4 \\
\hline$>10$ years & 79 & 20.3 \\
\hline 5.2. Substance abuse and Stress relieving &
\end{tabular}

The majority $169(43.4 \%)$ of the study participants worked for 5-10 years in AHMC. Regarding substance abuse, Most of 333(85.6\%) the study participants do not drink alcohol but out those who drink alcohol, more than half $31(55.4 \%)$ of them drink once per week, the majority $355(91.3 \%)$ do not chew kchat and out of those who chew kchat, half $17(50.0 \%)$ chew once in a week. And almost 378(97.2\%) do not smoke shisha and $9(81.9 \%)$ of shisha smokers smokes two and more times per week. More than half of study participants 209(53.7\%) do not recreate to relieve work related stress at the weekends. Out of those who recreate themselves at weekend about 53(29.3\%) and 49(27.1\%) recreate themselves at visiting cafeteria and religious places respectively. The majority $283(72.8 \%)$ of the workers do not take annual leave and refresh their mind.

( Table 2 here ) 
Table 2

Substance abuse and stress reliving characteristics of AHMC staffs, 2016

\begin{tabular}{|c|c|c|}
\hline Variables & Frequency & Per cent \\
\hline \multicolumn{3}{|c|}{ Drinking alcohol } \\
\hline No & 333 & 85.6 \\
\hline Yes & 56 & 14.4 \\
\hline \multicolumn{3}{|c|}{ Frequency of Drinking } \\
\hline Once/Week & 31 & 55.4 \\
\hline Twice/Week & 13 & 23.2 \\
\hline 3 days/week & 3 & 5.4 \\
\hline 4 days/week & 2 & 3.6 \\
\hline 6 days/week & 1 & 1.8 \\
\hline Daily & 6 & 10.7 \\
\hline \multicolumn{3}{|c|}{ Amount of drinking in bottles } \\
\hline \multicolumn{3}{|l|}{ Chewing kchat } \\
\hline No & 355 & 91.3 \\
\hline Yes & 34 & 8.7 \\
\hline \multicolumn{3}{|c|}{ Frequency of chewing } \\
\hline Once/Week & 17 & 50.0 \\
\hline Twice/Week & 1 & 2.9 \\
\hline 3 days/week & 8 & 23.5 \\
\hline 4 days/week & 3 & 8.8 \\
\hline 5 days / week & 4 & 11.8 \\
\hline Daily & 1 & 2.9 \\
\hline \multicolumn{3}{|c|}{ Smoking Shisha } \\
\hline No & 378 & 97.2 \\
\hline Yes & 11 & 2.8 \\
\hline \multicolumn{3}{|c|}{ frequency of smoking } \\
\hline Once/Week & 2 & 18.2 \\
\hline Twice/Week & 3 & 27.3 \\
\hline
\end{tabular}




\begin{tabular}{|lll|}
\hline Variables & Frequency & Per cent \\
\hline 3 days/week & 3 & 27.3 \\
\hline Daily & 3 & 27.3 \\
\hline recreate to relieve stress & & \\
\hline No & 209 & 53.7 \\
\hline Yes & 180 & 46.3 \\
\hline Place of Recreation & & \\
\hline Cafeteria & 53 & 29.3 \\
\hline Hotels \& Restaurants & 14 & 7.7 \\
\hline Historical Heritages & 14 & 7.7 \\
\hline Recreational places & 37 & 20.4 \\
\hline Religious places & 49 & 27.1 \\
\hline Others & 14 & 7.7 \\
\hline Department You are working now & & \\
\hline Are you happy with working in the department & & \\
\hline No & 116 & 29.8 \\
\hline Yes & 273 & 70.2 \\
\hline Do you take annual leave every year & & \\
\hline No & 283 & 72.8 \\
\hline Yes & 106 & 27.2 \\
\hline Naled FaCtOrs & \\
\hline
\end{tabular}

\subsection{Job related Factors}

This study assessed the work related factors that may have effect on employee satisfaction. Of all study participants $108(27.8 \%)$ of them were not satisfied with their work environment. In relation to job security still only $133(34 \%)$ are feeling that they are secured. Regarding co-worker relationship more than half $187(56.0 \%)$ of the study participants are satisfied by their co-workers relation in the work environment. More than 270(69.4\%) of the study participants have satisfied by the relationship with their supervisors. Autonomy of workers is very important at the work condition. In this study, only $180(46.3 \%)$ of study participants are feeling that they are autonomous in their work area. Regarding their work load more than $235(60.4 \%)$ of them were satisfied by their work load.

(Table 3 here) 
Table 3

job related factors among AHMC employees

\begin{tabular}{|c|c|c|c|c|c|}
\hline Variables & $\begin{array}{l}\text { Very } \\
\text { Dissatisfied }\end{array}$ & Dissatisfied & Neutral & Satisfied & $\begin{array}{l}\text { Very } \\
\text { Satisfied }\end{array}$ \\
\hline $\begin{array}{l}\text { Work Environment } \\
\text { Category }\end{array}$ & $21(5.4 \%)$ & $87(22.4 \%)$ & $171(44 \%)$ & $91(23.4 \%)$ & $19(4.9 \%)$ \\
\hline Job Security issue & $25(6.4 \%)$ & $110(28.3 \%)$ & $121(31.1 \%)$ & $96(24.7 \%)$ & $37(9.5 \%)$ \\
\hline Co-worker relationship & $3(0.8 \%)$ & $30(7.7 \%)$ & $138(35.5 \%)$ & $150(38.6 \%)$ & $68(17.5 \%)$ \\
\hline $\begin{array}{l}\text { Relationship with } \\
\text { supervisor }\end{array}$ & $20(5.1 \%)$ & $30(7.7 \%)$ & $115(29.6 \%)$ & $115(29.6 \%)$ & $155(39.8 \%)$ \\
\hline $\begin{array}{l}\text { Autonomy Related } \\
\text { issue }\end{array}$ & $10(2.6 \%)$ & $50(12.9 \%)$ & $149(38.3 \%)$ & $135(34.7 \%)$ & $45(11.6 \%)$ \\
\hline Work load issue & $9(2.3 \%)$ & $30(7.7 \%)$ & $115(29.6 \%)$ & $179(46.0 \%)$ & $56(14.4 \%)$ \\
\hline
\end{tabular}

\subsection{Organizational, Managerial and Payment related issues}

This study assessed organizational commitment and managerial related issues. Almost less than 155 (39.3\%) of study participants showed (satisfied) commitment to the organization. Regarding employee participation in planning and other managerial activities, only $85(21.9 \%)$ of the employee was satisfied in participating with decision making of the college. And only 84 (21.6\%) of the study participants were satisfied by employee performance appraisal system. Concerning the promotion and growth of the study participants, only $77(19.8 \%)$ of the employees were satisfied. Of the total study participants about 93 $(23.9 \%)$ of them were satisfied, $160(41.1 \%)$ were neutral and more than one third $136(35.0 \%)$ were not satisfied by their leadership. Again concerning the payment related issue, less than one fifth $68(17.5 \%)$ of the study participants were satisfied.

(Table 4 here ) 
Table 4

Organizational, Managerial and Payment related characteristics among AHMC employees`

\begin{tabular}{|llllll|}
\hline Variables & $\begin{array}{l}\text { Very } \\
\text { Dissatisfied }\end{array}$ & Dissatisfied & Neutral & Satisfied & $\begin{array}{l}\text { Very } \\
\text { Satisfied }\end{array}$ \\
\hline $\begin{array}{l}\text { Organizational } \\
\text { Commitment }\end{array}$ & $3(0.8 \%)$ & $30(7.7 \%)$ & $201(51.7 \%)$ & $137(35.2 \%)$ & $18(4.6 \%)$ \\
\hline $\begin{array}{l}\text { Employee participation in } \\
\text { decision making }\end{array}$ & $65(16.7 \%)$ & $89(22.9 \%)$ & $150(38.6 \%)$ & $63(16.2 \%)$ & $22(5.7 \%)$ \\
\hline $\begin{array}{l}\text { Performance appraisal } \\
\text { system }\end{array}$ & $71(18.3 \%)$ & $91(23.4 \%)$ & $143(36.8 \%)$ & $71(18.3 \%)$ & $13(3.3 \%)$ \\
\hline $\begin{array}{l}\text { Promotion/Growth } \\
\text { opportunity }\end{array}$ & $18(4.6 \%)$ & $114(29.3 \%)$ & $180(46.3 \%)$ & $58(14.9 \%)$ & $19(4.9 \%)$ \\
\hline $\begin{array}{l}\text { Organizational leadership } \\
\text { Payment related Issues }\end{array}$ & $41(10.5 \%)$ & $95(24.4 \%)$ & $160(41.1 \%)$ & $83(21.3 \%)$ & $10(2.6 \%)$ \\
\hline $\mathbf{5}$ & $28(7.2 \%)$ & $128(32.9 \%)$ & $165(42.4 \%)$ & $40(10.3 \%)$ & $28(7.2 \%)$ \\
\hline
\end{tabular}

\subsection{Satisfaction level}

The overall level of satisfaction of study participants among AHMC staff is low and accounts only 185 $(47.6 \%)(\mathrm{Cl}: 1.43,1.53)$. Professional status of study participants were analysed for level of satisfaction. See the table below

(Table 5 here) 
Table 5

Satisfaction level among AHMC in relation to their professional status

\begin{tabular}{|lll|}
\hline Study Participants Profession & Not Satisfied & Satisfied \\
\hline Nurses & $72(51.1 \%)$ & $69(48.9 \%)$ \\
\hline Midwifes & $24(77.4 \%)$ & $7(22.6 \%)$ \\
\hline General Practitioners & $4(50 \%)$ & $4(50 \%)$ \\
\hline Pharmacy Professionals & $8(44.4 \%)$ & $10(55.6 \%)$ \\
\hline Medical Laboratory Professionals & $20(87.0 \%)$ & $3(13 \%)$ \\
\hline Radiology Professionals & $10(50 \%)$ & $10(50 \%)$ \\
\hline Specialists & $11(42.3 \%)$ & $15(57.7 \%)$ \\
\hline Accountants & $20(40.8 \%)$ & $29(59.2 \%)$ \\
\hline Management Professionals & $24(54.5 \%)$ & $20(45.5 \%)$ \\
\hline IT professionals & $5(38.5 \%)$ & $8(61.5 \%)$ \\
\hline Others including academic staffs & $6(37.5 \%)$ & $10(62.5 \%)$ \\
\hline
\end{tabular}

(Fig. 3 here)

\subsection{Determinants of Job satisfaction}

Univariate analysis has been conducted and variable with $p$-value $<0.25$ were candidate for multivariable logistic regression. Finally, variables like smoking shisha, work environment situations, co-workers relationship, relationship with immediate supervisors, autonomy at work place, organizational commitment, performance appraisal and promotional or growth opportunity showed significant association.

The odd of shisha smoker workers is $0.40(\mathrm{AOR}, 0.4 ; 95 \% \mathrm{Cl}: 0.01,0.44)$ times lower compared to the counterpart. This shows negative association between shisha smoker workers and satisfaction levels. The odd of good working environment is 4.08 (AOR, 4.08; 95\% Cl: 1.98, 8.41) times higher than not good working environment. Co-workers relationship has been assessed and the odd of works that have good relationship with co-workers is 2.85 (AOR, 2.85; 95\% Cl: 1.21, 6.72) times higher than those who have no good relationship with co-workers. The odds of supportive relationship with immediate supervisor is 4.59 (AOR, $4.59 ; 95 \% \mathrm{Cl}: 1.89,11.19$ ) is higher compared to the counterpart. Autonomy of workers regarding their working condition has been assessed. The result of this study shows that the odd of workers that have autonomy at their working condition is 4.40 (AOR, $4.40 ; 95 \% \mathrm{Cl}: 1.89,11.19)$ times higher compared to those not have autonomy at their work condition. Workers commitment for the survival of their organization has been assessed and the odd of worker who have high commitment for their organization 
is 2.48 (AOR, $2.48 ; 95 \% \mathrm{Cl}: 1.20,5.10)$ times higher compared to their counterpart. Performance evaluation was one concern for workers satisfaction, the result of this study shows that the odd of workers who believe that performance evaluation is good is 5.69 (AOR, $5.69 ; 95 \% \mathrm{Cl}: 2.53,12.80$ ) times higher compared to others. The odd of workers who trust treatment of promotion or growth opportunity is fair is 9.58 (AOR, 9.58; $95 \% \mathrm{Cl}: 4.11,22.32)$ times higher compared to their counterpart.

( Table 6 here) 
Table 6

; Determinants of satisfaction level of study participants of AHMC

\section{Variables}

Satisfaction level

Satisfied
COR

AOR

Not

Satisfied

\section{Educational status}

Below level IV diploma

$17(54.8 \%) \quad 14(45.2 \%) \quad 1.00$

Level IV \& Diploma

$28(42.4 \%) \quad 38(57.6 \%)$

$0.26(0.26,1.43)$

$1.92(0.39,9.54))$

1st Degree

$121(46.2 \%) \quad 141(53.8 \%)$

$0.36(0.34,1.49)$

$0.28(0.07,1.12)$

2nd Degree

$19(63.3 \%)$

$11(36.7 \%)$

$0.50(0.51,3.97)$

$0.31(0.05,1.90)$

\section{Shisha smoking}

No

$182(48.1 \%)$

$196(51.9 \%)$

1.00

$3(27.3 \%) \quad 8(72.7 \%)$

$0.40(0.11,1.55)$

0.40(0.01, $0.44)^{\star \star}$

\section{Situation of working}

environment

Not Good

$40(20.5 \%) \quad 155(79.5 \%) \quad 1.00$

Good

$145(74.7 \%)$

$49(25.3 \%)$

11.47(7.13,

18.44)

4.08(1.98,

$8.41)^{\star \star}$

\section{Co-Workers relationship}

Not Good

$56(28.0 \%) \quad 144(72.0 \%) \quad 1.00$

Good

$129(68.3 \%)$

$60(31.7 \%)$

$5.53(3.58,8.54)$

2.85(1.21

$6.72)^{\star *}$

\section{Relationship with supervisors}

Not supportive

\begin{tabular}{lll}
\hline $42(23.7 \%)$ & $135(76.3 \%)$ & 1.00 \\
\hline $143(67.5 \%)$ & $69(32.5 \%)$ & $\begin{array}{l}6.66(4.25, \\
10.45)\end{array}$
\end{tabular}

4.59(1.89,

Supportive

$\begin{array}{llll}54(25.8 \%) & 155(74.2 \%) & 1.00 & \\ 131(72.8 \%) & 49(27.2 \%) & \begin{array}{l}7.67(4.89, \\ 12.05)\end{array} & \begin{array}{l}4.40(2.00, \\ 9.67)^{\star \star}\end{array}\end{array}$

\section{Organizational Commitment}

${ }^{* *}=$ Associated at p-value $0.05(\mathrm{Cl}=95 \%)$ 


\begin{tabular}{|c|c|c|c|c|}
\hline \multirow[t]{2}{*}{ Variables } & \multicolumn{2}{|c|}{ Satisfaction level } & \multirow[t]{2}{*}{ COR } & \multirow[t]{2}{*}{ AOR } \\
\hline & Satisfied & $\begin{array}{l}\text { Not } \\
\text { Satisfied }\end{array}$ & & \\
\hline Low & $56(29.3 \%)$ & $135(70.7 \%)$ & 1.00 & \\
\hline High & $129(65.2 \%)$ & $69(34.8 \%)$ & $4.51(2.94,6.91)$ & $\begin{array}{l}2.48(1.20 \\
5.10)^{\star \star \star}\end{array}$ \\
\hline \multicolumn{5}{|c|}{ Performance Appraisal } \\
\hline Not Good & $40(20.5 \%)$ & $155(79.5 \%)$ & 1.00 & \\
\hline Good & $145(74.7 \%)$ & $49(25.3 \%)$ & $\begin{array}{l}\text { 11.47(7.13, } \\
18.44)\end{array}$ & $\begin{array}{l}5.69(2.53 \\
12.80)^{\star \star}\end{array}$ \\
\hline \multicolumn{5}{|c|}{ Promotional opportunity } \\
\hline Unfair & $43(20.7 \%)$ & $165(79.3 \%)$ & 1.00 & \\
\hline Fair & $142(78.5 \%)$ & $39(21.5 \%)$ & $\begin{array}{l}13.97(8.58, \\
22.76)\end{array}$ & $\begin{array}{l}9.58(4.11, \\
22.32)^{\star \star}\end{array}$ \\
\hline
\end{tabular}

\section{Discussion}

In this study the level of employee satisfaction was assessed and the result showed that $47.60 \%$ of the study participants were satisfied by their job. The result of this study is higher with the studies conducted in different organizations of America (38\%)(11), in western parts of Amhara region (Ethiopia) among health workers (31.7\%)(14), in western part of Ethiopia among different employees (41.46\%)(13), among Anaesthesia ( 42.5\%) in Ethiopia (19) and n Jimma university health workers (46.2\%) Ethiopia(17). In another way, the result of this study is lower than the study conducted among Mekelle academic staff $(50.4 \%)(15)$, Ethiopia among modifiers (52.9\%)(20), in Gojam among nurses (54.2\%)(16) and in south western of Ethiopia among nurses $(67.43 \%)(18)$. The discrepancy may be due to study participants, study design geographical location study period and working conditions.

Substance abuse (shisha smoking) shows significant association. The odds of shisha smoking among smokers are low. There is no data which shows that substance abuse of employee can affect their job satisfaction of them. Another factor which shows significant association with job satisfaction among Adama Hospital Medical College workers was working environment. The result of this study is similar with the study conducted in Pakistan and Sidama, southern part of Ethiopia respectively $(24,25)$. But the result of this study is different from the study conducted in Bangladesh in which employees are dissatisfied with their working environment(23). The similarity and difference may be characteristics of working organization, facilities and levels of organizations. 
Relationship shows significant association with employee job satisfaction. Co-workers relationship shows strong association with employees' job satisfaction. The result of this study is conducted in Bangladesh, Bogor Regency Sectarian (Indonesia), India and Addis Ababa(Ethiopia) $(20,23,26,28)$. Similarity may be due to the fact that good co-workers relationships create good communication and facilitate good working condition and satisfaction in job.

Relationship with immediate supervisor was one of the factors which show significant association with employee job satisfaction. The result of this study is consistent with the studies conducted in India, solevenian, Indonesia and India $(26,27)$. The similarity may due to the fact that if there is supportive supervision from immediate supervision, the employee may be motivated and satisfied by their job.

Autonomy of workers on their job shows significant association with the employees' job satisfaction. The result of this study is similar with study conducted in Florida (21), Spain(22), India (29)and Bangladesh telecommunication(30). The similarity may be due to the fact that if the employees are autonomized on their work they feel free and perform their work freely. This may leads to employees' job satisfaction. Another factor that affects job satisfaction is organizational commitment. In this study, organizational commitment shows significant association with employees 'job satisfaction. The result of this study is similar with the study conducted in Florida(21) and Spain (22). This may be due to that if employees are committed to the organization they are working with they feel comfortable and work properly. This may again leads to job satisfaction.

Performance appraisal is one of the major factors that may affect employees ' job satisfaction. In this study, performance appraisal shows significant association with job satisfaction. The result of this study is consistent with study conducted in India(26) and Bangladesh(23). The association may be due to the fact that each employee should be assessed based on their plan and standard set by the organization but if this is not true it will affect employees' job satisfaction.

Factors like developmental and promotional strategies can affect employees' job satisfaction. The result of this study shows that promotional strategies have significant association with employees` job satisfaction. It is similar with the studies conducted in India(26,28), Bangladesh(23), northwest Ethiopia(16) and Addis Ababa(20). This may be due to the fact that fairness can affect the developmental life of workers and if promotional strategy is not fair and clear, it will affect the life and psychology of workers. This will leads to dissatisfaction of employees`on their job.

\section{Strength And Limitation}

\subsection{Strength}

This study tried to find out employees feeling and their commitment to their organization and new and original data was collected from all department of the study organization.

\subsection{Limitations}


Workers may over report that they are satisfied on their job fearing treatment of organizational management (social desirability).

\section{Conclusions}

The overall job satisfaction among study population is $47.60 \%$ which is low, less than $50 \%$ of employees are satisfied with their job. Factors like substance abuse (Shisha smoking), working environment, coworkers and immediate supervisors' relationship, Autonomy, Organizational commitment, performance appraisal and Promotional strategies shows significant association with employees` job satisfaction.

\section{Recommendations}

AHMC

- Creating recreation time and place in order to make workers not to abuse substance, and making release of stress that may be due to working situation of the organization.

- Creating save and interesting working environment in the organization

- Making meeting to discuss with co-workers and immediate supervisor (department heads) and trying to remove any uncomforted by making discussion with general employees meeting.

- Most of workers are not feeling that they are autonomized by their work; therefore, the organization, co-workers and immediate supervisors should give autonomy to each employee on their work.

- Most workers show low commitment to the organization, therefore, they do not feel that the organization will benefit them. The organization should handle fairly all workers' matters ( equal opportunity and equity) among employee and should share organizations vision, mission and values.

- Large numbers of employees` were not satisfied by the performance appraisal. Therefore, measurement of performance appraisal should be developed fair, objective based, customer based and standardized versus planned activities.

- More than half of study participants reported that promotional strategy was not fair. Therefore, the organization should develop fair and clear developmental and promotional strategies.

Oromia Regional Health Bureau

- Some of factors like performance appraisal performance and promotional strategies should be revised, fair, clear and be made based on organizational standards.

\section{Declarations}

\section{Funding}


This research project was supported by the Adama Hospital Medical College under Grant 0692/k-373/11 for data collection and analysis

\section{Conflict of interest}

No any financial conflict of interet that arises due to this research

\section{Data availability statement}

The authors confirm that tha data supporting the finding of this study are available within the articles and/or its supplementary materials and can be shared upon requested for any person or organization and available with the corresponding author at any time.

\section{Acknowledgement}

The authors want to acknowledge all Adama Hospital Medical College staffs for their genuine information and giving time to participate in this research. The authors recognizes and thanks Adama Hospital Medical College for funding and supporting this research for data collection and analysis.

\section{References}

1. Wernerfelt B. A Resource-Based View of the Firm. Strategic Management Journal Apr - Jun. 1984;5(2):171-80.

2. Porter ME. Competitive Advantage; Creating And Sustaining Superior Peifonnance. NEW YORK: THE FREE PRESS; A Division of A1acmillan, Inc.; 1985.

3. Schneider B. Organizational Climate. Personnel Psychology. 28 1987. p. 447-79.

4. Cranny CJ, Smith PC, Stone EF. Job satisfaction: How people feel about their jobs and how it affects their performance New York, Lexington Books, NY; 1992.

5. Spector Paul E Job Satisfaction: Application, Assessment, Causes, and Consequences: SAGE Publications, Inc; 1997.

6. Judge TA, Thoresan CJ, Bono. JE, Patton GK. The Employee Satisfaction- Employee Performance Relationship: A Qualitative and Quantitative Review. Psychol Bull. 2001;127(3):376-407.

7. Mosammod Mahamuda Parvin. Factors Affecting Employee Job Satisfaction Of Pharmaceutical Sector. Australian Journal of Business Management Research December-. 2011;1(9):113-23.

8. HACKMAN JR, OLDHAM GR. Development of the Job Diagnostic Survey. J Appl Psychol. 1975;60(2):159-70.

9. New Cranny CJ, Smith PC, Stone EF. Job satisfaction: How people feel about their jobs and how it affects their performance. New York: Lexington; 1992.

10. Lise MSaari, Ttimothy A, Judge. Employee attitudes and job satisfaction. Hum Resour Manag. 2004;43(4):395-407. 
11. Christina Lee MA, Evren Esen DiNicolaS. Employee Job Satisfaction And Engagement: The Doors Of Opportunity Are Open. USA: SHRM; 2016.

12. Mulu Aderie Alemu. An Assessment on Job Satisfaction of Academic Employees: A Survey on Ethiopian Private Institutions of Higher Learning... 2013;4(12):138-45.

13. Deriba BK, Sinke SO. BME, Abebe Sorsa Badacho. Health professionals' job satisfaction and associated factors at public health centers in West Ethiopia. BMC Human Resources for Health. 2017;15(36):15(36):2-7.

14. Kalkidan Temesgen M. Job satisfaction and associated factors among health professionals working at Western Amhara Region, Ethiopia. BMC:Health Quality of Life Outcomes. 2018;16(65):1-7.

15. Hagos G. Kebede Abrha. Study on factors affecting Job Satisfaction in Mekelle University Academic staff at Adi-Haqi campus. International Journal of Scientific Research Publications January. 2015;5(1):1-6.

16. Haile D, Gualu T, Zeleke H, Dessalegn B. Assessment of Job Satisfaction and Associated Factors among Nurses in East Gojjam Zone Public Hospitals Northwest Ethiopia, 2016. Journal of Nursing \& Care. 2017;06(03).

17. Alemshet Yami L, Hamza A, Hassen C, Jira, Morankar Sudhakar. Job Satisfaction And Its Determinants Among Health Workers In Jimma University Specialized Hospital, Southwest Ethiopia. Ethiop J Health Sci August. 2011;21(Special Issue):20-7.

18. Ayele S. Nurses Job Satisfaction in Public Hospitals of South West Region of Ethiopia, 2014. Ergonomics International Journal October. 2017;09(3):000113. 1(.

19. Kibwana S, Yigzaw MMY, van Roosmalen J, Stekelenburg J. Job satisfaction among anesthetists in Ethiopia-a national cross-sectional study. Int J Health Plann Mgmt. 2018;2018:1-11. https://doiorg/0. 1-11.

20. Bekru ET, Cherie A, Anjulo AA. Job satisfaction and determinant factors among midwives working at health facilities in Addis Ababa city, Ethiopia. PLoS One. 2017;12(2):1-16.

21. Lane KAEJ, Holte B, McCusker MA. A study of nurse faculty job satisfaction in community colleges in Florida Teach. Learn Nurse. 2010;5:16-26.

22. Vidal MESVR, Aragón BMI. Antecedents of repatriates' job satisfaction and its influence on turnover intentions: Evidence from Spanish repatriated managers. J Bus Res. 2007;60:1272-81.

23. Mostafizur Rahmani R, Akhter S, Chowdhury S, Islam. Md. Reiazul Haque. HRM Practices and its Impact on Employee Satisfaction: A Case of Pharmaceutical Companies in Bangladesh. International Journal of Research in Business and Social Science IJRBS 2013;2(3).

24. Asegid A, Belachew T, Yimam E. Factors Influencing Job Satisfaction and Anticipated Turnover among Nurses in Sidama Zone Public Health Facilities, South Ethiopia. Nurs Res Pract. 2014;2014:Article ID 909768, 26 pages..

25. Waqas A, Bashir U, Sattar MF, Abdullah HM, Hussain I, Anjum W, et al. Factors Influencing Job Satisfaction and Its Impact on Job Loyalty. International Journal of Learning \& Development. $2014 ; 4(2)$. 
26. Sharma AaK M. Job satisfaction among bank employees -a study on district hamirpur (H.P.). International Journal of Science Environment Technology. 2014;3(4):1582-91.

27. Lorber M, Skela Savič B. Job satisfaction of nurses and identifying factors of job satisfaction in Slovenian Hospitals. Croatian Medical Journal. 2012;53(3):263-70.

28. Kadarisman M. Analysis on Factors that Influence Job Satisfaction of Government Employees. Journal of Administrative Science \& Organization.19(1).

29. Prerana.,Factors Influencing Job Satisfaction. A Study Done On The Employees Of Public Sector Undertaking In Delhi. International Journal of Management Studies June. 2017;4(1):154-63.

30. Ethica Tanjeen. A study on factors affecting job satisfaction of Telecommunication industries in Bangladesh. IOSR Journal of Business Management (IOSR-JBM). 2013;8(6):80-6.

\section{Figures}

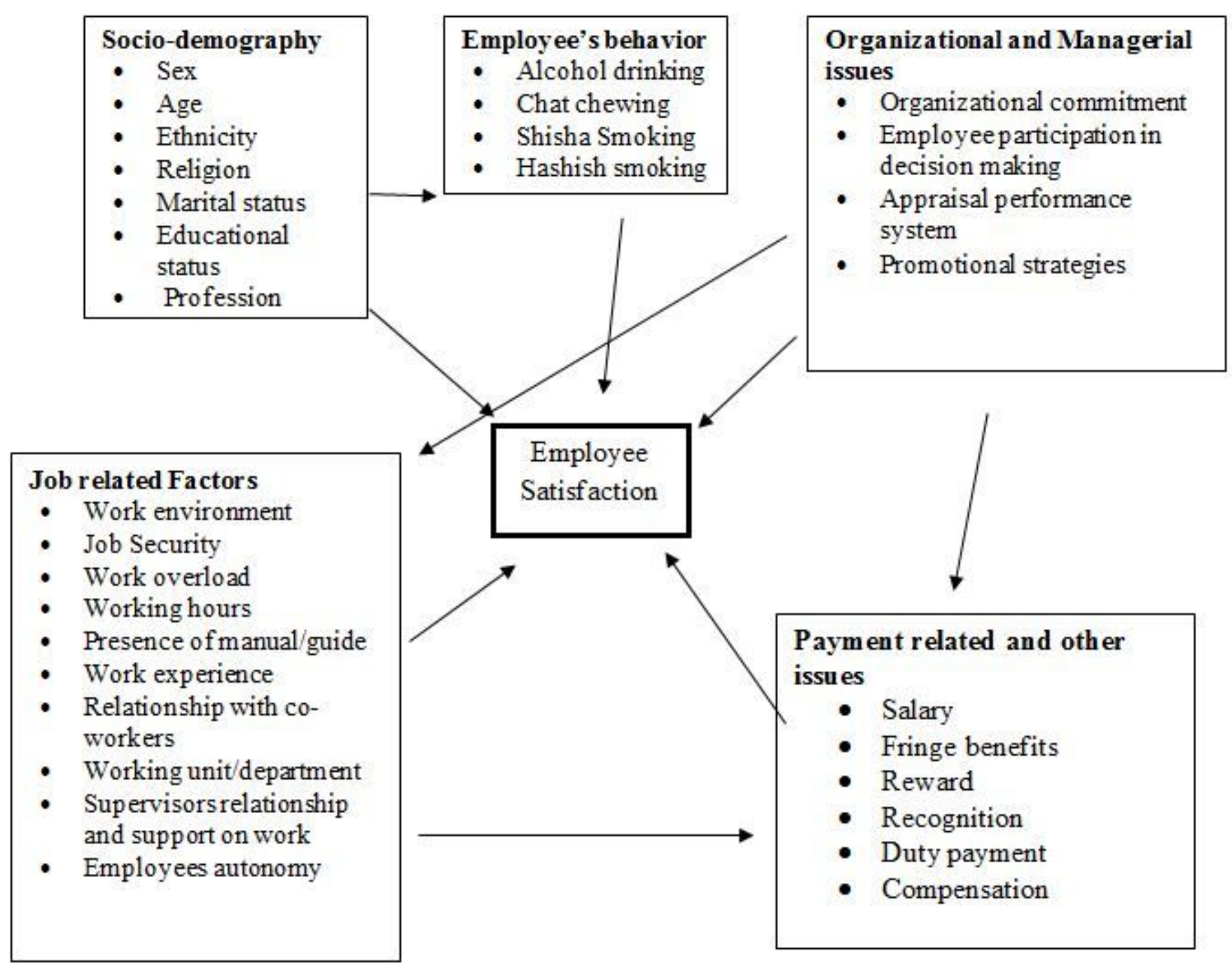

Figure 1 
Conceptual framework for assessment of employee satisfaction and associated factors among employees working in Adama Hospital Medical College , Ethiopia, 2019 (Source: Adapted from Literature review)

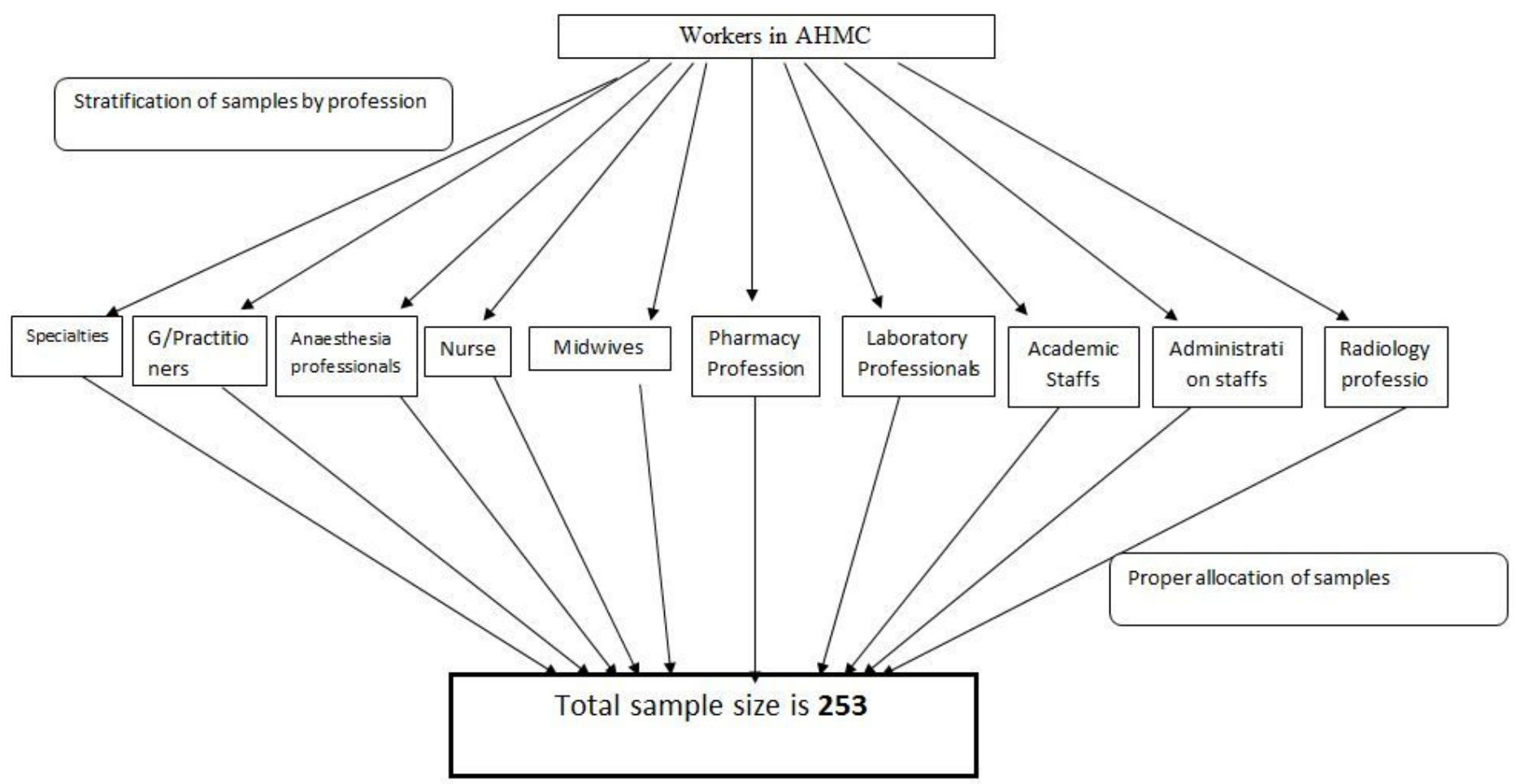

Figure 2

Schematic representation of sampling procedure

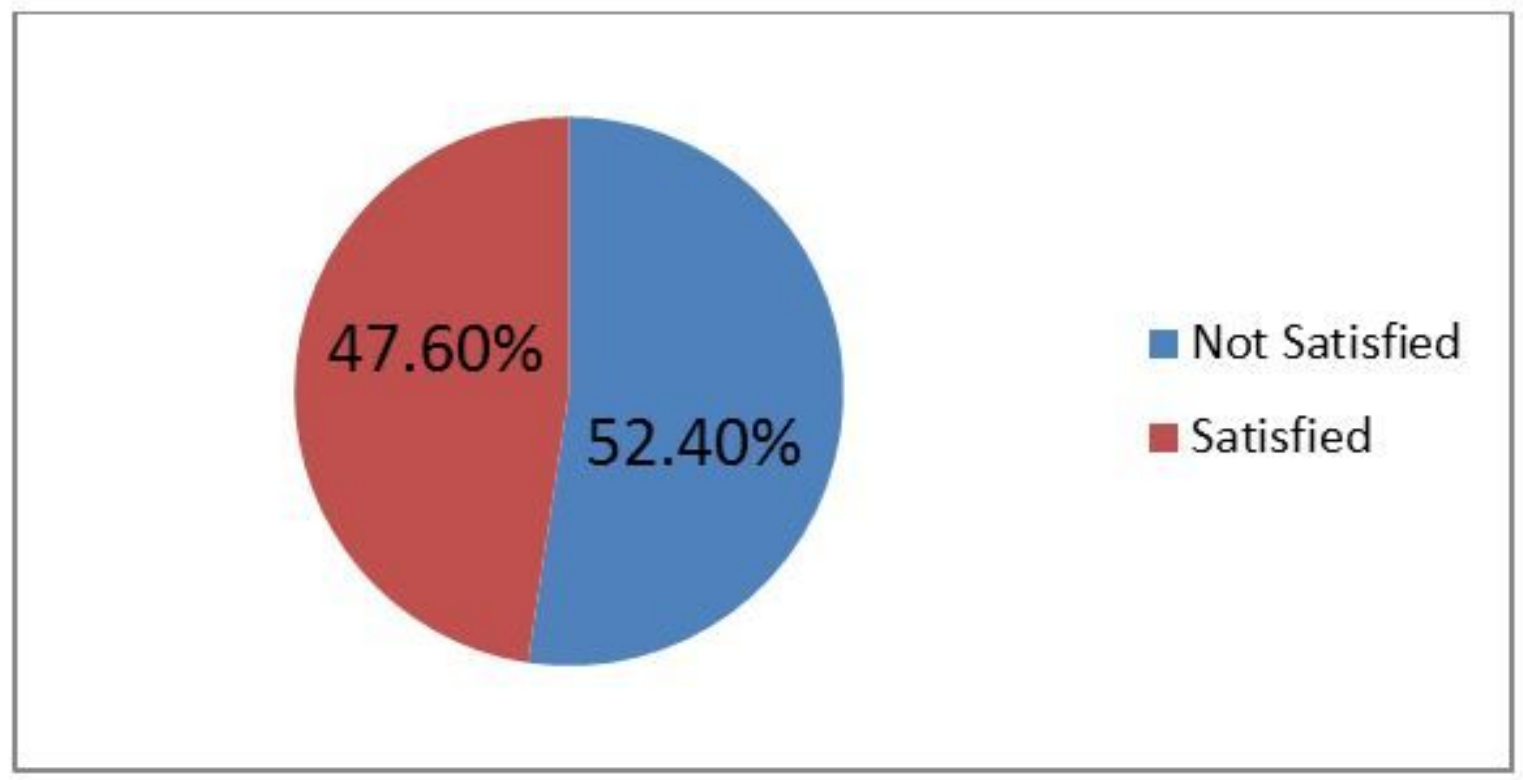

Figure 3 
Satisfaction level of study participants of AHMC 